\title{
Analysis and Optimization of Axial Flux Permanent Magnet Machine for Cogging Torque Reduction
}

\author{
Hina Usman ${ }^{1}$, Junaid Ikram ${ }^{1}$, Khurram Saleem Alimgeer ${ }^{1}{ }^{(\mathbb{D}}$, Muhammad Yousuf ${ }^{2}{ }^{(\mathbb{C}}$, \\ Syed Sabir Hussain Bukhari ${ }^{3,4}$ and Jong-Suk Ro ${ }^{4,5, *(D)}$ \\ 1 Electrical and Computer Engineering Department, Islamabad Campus, COMSATS University Islamabad, \\ Islamabad 45550, Pakistan; hinausman93@gmail.com (H.U.); Junaidikram@comsats.edu.pk (J.I.); \\ khurram_saleem@comsats.edu.pk (K.S.A.) \\ 2 Electrical and Computer Engineering Department, Abbottabad Campus, COMSATS University Islamabad, \\ Islamabad 22060, Pakistan; m.yousaf891@gmail.com \\ 3 Department of Electrical Engineering, Sukkur IBA University, Sukkur 65200, Pakistan; sabir@iba-suk.edu.pk \\ 4 School of Electrical and Electronics Engineering, Chung-Ang University, Seoul 06910, Korea \\ 5 Department of Intelligent Energy and Industry, Chung-Ang University, Seoul 06910, Korea \\ * Correspondence: jongsukro@gmail.com
}

Citation: Usman, H.; Ikram, J.; Alimgeer, K.S.; Yousuf, M.; Bukhari, S.S.H.; Ro, J.-S. Analysis and Optimization of Axial Flux Permanent Magnet Machine for Cogging Torque Reduction. Mathematics 2021, 9, 1738. https://doi.org/10.3390/ math9151738

Academic Editors: Vladimir Prakht, Mohamed N. Ibrahim and Aleksey S. Anuchin

Received: 7 July 2021

Accepted: 20 July 2021

Published: 23 July 2021

Publisher's Note: MDPI stays neutral with regard to jurisdictional claims in published maps and institutional affiliations.

Copyright: (c) 2021 by the authors. Licensee MDPI, Basel, Switzerland. This article is an open access article distributed under the terms and conditions of the Creative Commons Attribution (CC BY) license (https:/ / creativecommons.org/licenses/by/ $4.0 /)$.

\begin{abstract}
In this paper, a hexagonal magnet shape is proposed to have an arc profile capable of reducing torque ripples resulting from cogging torque in a single-sided axial flux permanent magnet (AFPM) machine. The arc-shaped permanent magnet increases the air-gap length effectively and makes the flux of the air-gap more sinusoidal, which decreases air-gap flux density and hence causes a reduction in cogging torque. Cogging torque is the basic source of vibration, along with the noise in PM machines, since it is the main cause of torque ripples. Cogging torque is independent of the load current and is proportional to the air-gap flux and the reluctance variation. Three-dimensional finite element analysis (FEA) is used in the JMAG-Designer to analyze the performance of the conventional and proposed hexagonal-shaped PM AFPM machines. The proposed shape is designed to reduce cogging torque, and the voltage remains the same as compared to the conventional hexagonalshaped PM machine. Further, optimization is performed by utilizing an asymmetric overhang. Latin hypercube sampling (LHS) is used to create samples, the kriging method is applied to approximate the model, and a genetic algorithm is applied to obtain the optimum parameters of the machine.
\end{abstract}

Keywords: Axial flux permanent magnet machine; 3D FEA; Genetic algorithm; hexagonal-shaped PMs; PM overhang

\section{Introduction}

Permanent magnet machines are divided into three categories-axial, radial, and transverse machines-depending upon the direction of flux through the air-gap. AFMs have several benefits over radial and transverse flux machines. They have high a powerto-weight ratio and easily modifiable air-gaps [1,2]. The axial flux permanent magnet (AFPM) machines are widely used, especially for power generation and electric vehicle (EVs) applications, due to their high power density and their compressed structure [3-9]. Furthermore, AFPM machines perform exceptionally well at a wide range of rotational speeds, which is appropriate for low-speed, high-torque characteristics. A single-sided AFPM machine is discussed in this paper due to its compact size and low cost. However, similar to other machines, single-sided AFPM machines also suffer from torque ripples, mainly due to cogging torque [10].

In PM machine design, cogging torque is a concern since it adds undesirable harmonics to torque. There are various techniques that exist to overcome cogging torque $[11,12]$. Skewing is the simplest, most common, and most effective technique used in PM machines to decrease the cogging torque. It also decreases the high order harmonics in the back-EMF 
waveform [13]. Cogging torque reduction is still a considerable issue in PM machines. Investigating methods of cogging torque minimization is of high importance, and various methods are discussed and investigated in other work [14-19].

Another technique of reducing cogging torque is the stator slots-to-rotor poles ratio. In the integral slot machines, components of cogging torque that are produced by all of the magnets are in phase with each other, which results in a high resultant cogging torque. However, in the fractional slot machines, components of the cogging torque are out of phase with each other [11]. Hence, the resultant cogging torque is reduced since some of the cogging components are partially canceled. Generally, it is desirable to use a combination of slot and pole numbers that has a higher least common multiple [20]. There are also different methods for reducing torque ripples; the shifting and stepping of rotor magnets is one of the most effective methods [21]. Three-dimensional FEA is utilized for a more precise performance analysis of the AFPM machine as compared to the analytical methods. To achieve high efficiency, stator-sided iron must not be saturated, and torque ripples should be nearby zero.

In the AFPM machine, the pole length is measured from the inner side to the outer diameter of the rotor back iron. The circumference of the outer side of the rotor is larger than the inner side. Consequently, to increase the active utilization of the surface area of the rotor, a hexagonal shape is more advantageous than a rectangular or circular shape. In practice, circular-shaped magnets may not be used in AFPM machines, especially when a higher number of poles is required [22].

A symmetrical, sinusoidal-shaped radial flux permanent magnet machine (RFPM) was designed, which removes the harmonics of back-EMF more effectively and has been proposed as a method for obtaining reduced cogging torque [23]. In [24], a trapezoidal arc-shaped is introduced to reduce torque ripples and cogging torque. In arc-shaped PM, the effective length of the air-gap is increased, which is not identical across the one magnet; it is at its maximum at the pole edges and reaches its minimum at the center of the pole. Hence, the increased length of an air-gap reduces the magnetic flux between magnets; therefore, cogging torque and torque ripples are reduced.

Generally, permanent magnet motors have an overhang structure in which the length of PM is longer than the length of the stator's stack. The overhang structure is commonly installed in PM machines to increase the air-gap flux density by concentrating magnetic flux [25]. The optimization of rotor overhang variation and PM overhang within the tangential direction is proposed to enhance the performance of AFPM machines.

Multi-objective optimization has received the most attention recently and is used in the optimization of electric machines. To improve the average output torque of the switched reluctance motor, a multi-objective optimization analysis is investigated in [26]. In [27], another optimization technique, based on particle swarm optimization (PSO), is discussed for cogging torque reduction and efficiency enhancement of the brushless DC motor. A 3D Pareto front linear induction motor with finite element model evaluation is optimized and analyzed in [28]. This paper performs the well-known, simple and practical optimization approach due to its suitability for non-linear data, as implemented in [29,30].

In this paper, a single-rotor, single-stator AFPM with a proposed PM shape is introduced. It utilizes the arc profile for the conventional hexagonal-shaped PM. The proposed hexagonal-shaped PM decreases the air-gap flux density, thus decreasing the cogging torque and torque ripple, which improves the performance of the machine. In addition, the optimization of the proposed model, which is obtained through a genetic algorithm (GA), further enhances its output characteristics by using asymmetric overhang. The research methodology, as described in [31], is presented in Figure 1. 


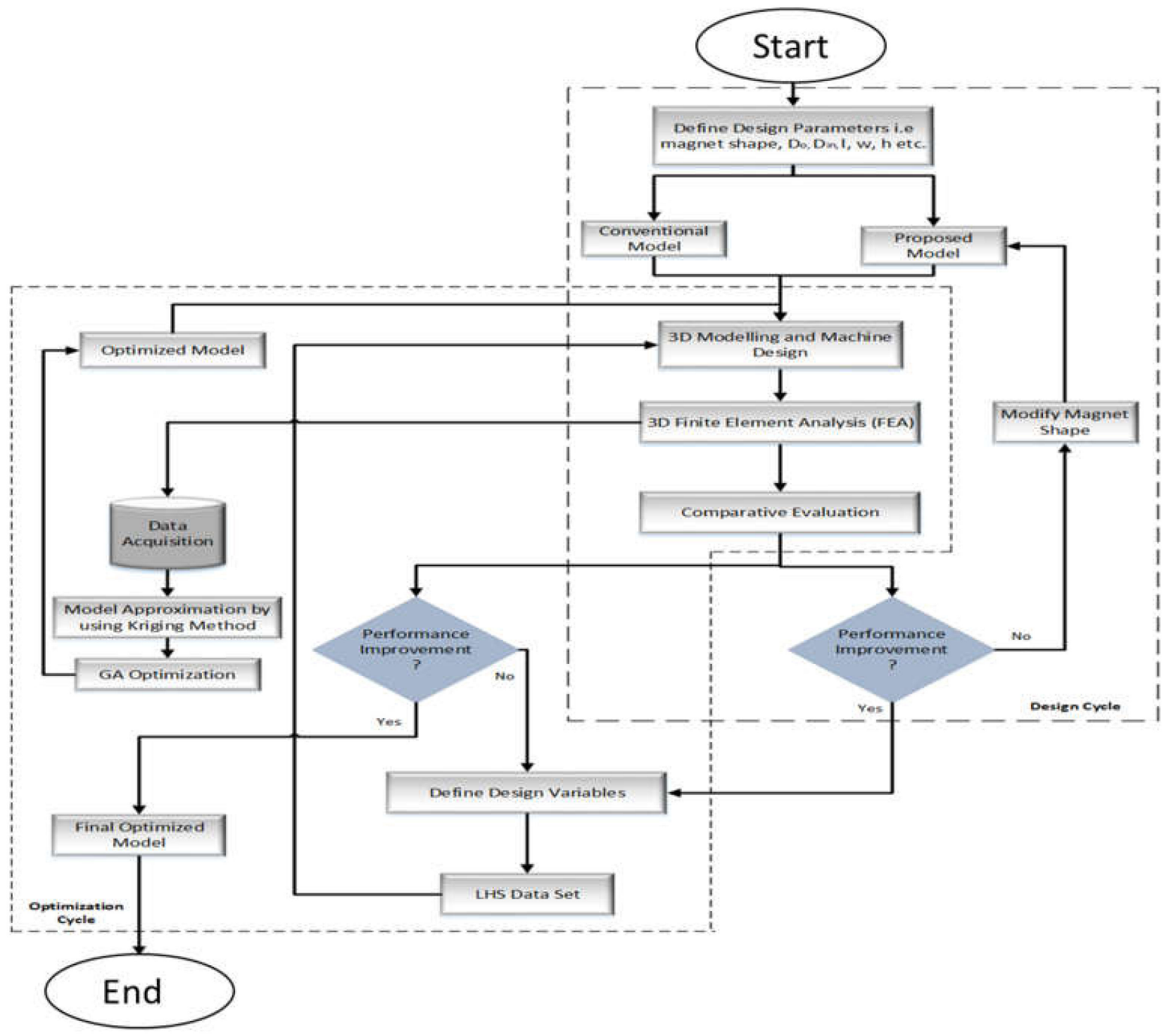

Figure 1. Flow chart of design and optimization process.

\section{Machine Topology and Design Process}

The single-sided machine is the most fundamental of these topologies for AFPM's. This arrangement contains one stator disc containing coils and one rotor disc containing magnets. Magnets in the rotor alternate between having south and north poles facing the stator, as shown in Figure 2.

In this topology, it is possible to attain a high ratio between the diameter and machine length. The topology normally consists of a compact design and offers low cost. The main disadvantage of single-sided topology is the major force attraction problem; because magnetic flux is coming from only one side, the attractive forces result in the bending of the yokes and high bearing losses. Table 1 shows the parameters of the basic model. The power of this machine is $2.5 \mathrm{~kW}$ and the frequency is about $700 \mathrm{~Hz}$. A SRSS machine, with 14 poles mounted on the rotor and 12 slots on the stator having a double-layer winding, is used in this research. 


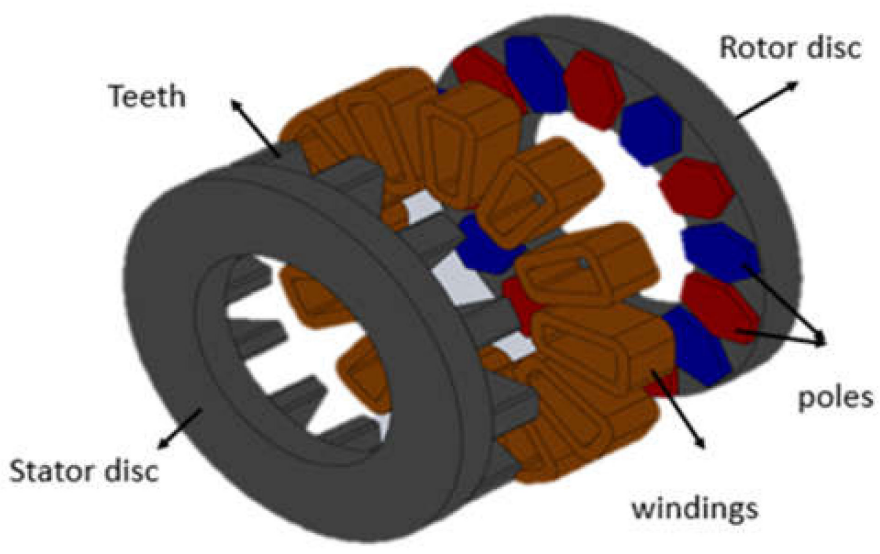

Figure 2. Single-rotor, single-stator axial flux permanent magnet machine.

Table 1. Main dimensions and operating parameters of the conventional and proposed models.

\begin{tabular}{ccc}
\hline Parameters & Conventional/Proposed & Units \\
\hline Outer diameter & 110 & $\mathrm{~mm}$ \\
Inner diameter & 64 & $\mathrm{~mm}$ \\
Axial length & $40 / 40.3$ & $\mathrm{~mm}$ \\
Stator slots depth & 15 & $\mathrm{~mm}$ \\
Stator slots width & 5 & $\mathrm{~mm}$ \\
Stator core thickness & 10 & $\mathrm{~mm}$ \\
Rotor core thickness & 12 & $\mathrm{~mm}$ \\
Operating speed & 6000 & $\mathrm{rpm}$ \\
Number of turns & 32 & - \\
Length of magnet $\left(\mathrm{L}_{\mathrm{m}}\right)$ & 22.5 & $\mathrm{~mm}$ \\
Side length $\left(\mathrm{L}_{\mathrm{n}}\right)$ & 12.5 & $\mathrm{~mm}$ \\
Width $\left(\mathrm{W}_{\mathrm{m}}\right)$ & 18 & $\mathrm{~mm}$ \\
Top and bottom width $\left(\mathrm{W}_{\mathrm{n}}\right)$ & 9.5 & $\mathrm{~mm}$ \\
Magnetic gap & 1 & $\mathrm{~mm}$ \\
Magnet thickness & $2.5 / 2.8$ & $\mathrm{~mm}$ \\
Arc height & $\mathrm{NA} / 1.8$ & $\mathrm{~mm}$ \\
Flat portion $\left(\mathrm{H}_{\mathrm{m}}\right)$ & $\mathrm{NA} / 1$ & $\mathrm{~mm}$ \\
Height of center $\left(\mathrm{H}_{\mathrm{n}}\right)$ & $\mathrm{NA} / 1.5$ & $\mathrm{~mm}$ \\
\hline
\end{tabular}

The mathematical discussion of the basic model that is briefly discussed here is the same as the one discussed in [21]. The input power calculations can be made as discussed in (1).

$$
P_{\text {in }}=2 \frac{m}{T} \int_{0}^{T} E_{m} \sin (\omega t) I_{m} \sin (\omega t) d t
$$

where $m, E_{m}$, and $I_{m}$ represent the phase numbers, the amplitude of back-EMF, and the phase current, respectively. The output power calculations are depicted in (2), where $\gamma$ represents efficiency [29-31].

$$
P_{\text {out }}=\gamma m E_{m} I_{m}
$$

The flux can be computed as in (3)

$$
\varphi=\varphi_{m} \cos \left(N_{p} \alpha_{r}\right)
$$

where $\varphi$ denotes the magnitude of flux, $\alpha_{r}$ shows the rotor position, and $N_{p}$ represents the number of rotor poles, respectively. The back-EMF can be expressed as in (4).

$$
e(t)=N_{p h} \omega_{r} N_{P} \varphi_{m} \sin \left(N_{p} \alpha_{r}\right)
$$


where $N_{p h}$ and $\omega_{r}$ show the phase coil turns and the angular speed of the rotor, respectively. By combining (1) and (2), back-EMF is determined as in (5).

$$
e(t)=N_{p h} \omega_{r} N_{P} k_{d} k_{f} B_{g} \alpha_{i} \frac{1}{N_{s}} \frac{\pi}{4}\left(D_{\text {out }}^{2}-D_{\text {in }}^{2}\right)
$$

where $k_{f}, k_{d}, B_{g}, N_{s}, D_{\text {out }}$, and $D_{\text {in }}$ represent the air-gap flux density coefficient, the lux leakage coefficient, the air-gap flux density, the slot numbers, the pole arc coefficient, and the outer and inner diameters of the rotor, respectively. The armature current is computed as in (6) [29-31].

$$
I_{m}=\frac{\sqrt{2} A_{e} \pi D_{i n}}{2 m N_{p h}}
$$

where $A_{e}$ shows the electrical loading. By putting the (3) and (4) in (2), the input power is given, as shown in (7).

$$
P_{\text {in }}=\frac{\sqrt{2 \pi^{3}}}{240} \frac{N_{p}}{N_{s}} k_{d} k_{f} k_{i o}\left(1-k_{i o}^{2}\right) A_{e} B_{g} \alpha_{i} D_{\text {out }}^{3} n_{r p m} \gamma
$$

where $k_{i o}$ represents the ratio of the inner and outer diameters and $n_{r p m}$ represents the rotor speed. Furthermore, the output torque can be computed as in (8).

$$
T_{\text {out }}=\frac{\sqrt{2}}{240} \pi^{2} \frac{N_{P}}{N_{s}} k_{d} k_{f} k_{i o}\left(1-k_{i o}^{2}\right) A_{e} B_{g} \alpha_{i} D_{\text {out }}^{3} \gamma
$$

It is very clear from (7) and (8) that the power and torque are dependent on the $A_{e}, B_{g}$, and $N_{p} / N_{s}$. From (7), the outer diameter can be represented as in (9).

$$
D_{\text {out }}=\sqrt[3]{\frac{240 P_{\text {out }} N_{s}}{\sqrt{2} \pi^{3} N_{r} k_{d} k_{f} k_{i o}\left(1-k_{i o}^{2}\right) A_{e} B_{g} \alpha_{i} n_{r p m} \gamma}}
$$

\section{Proposed and Optimized Model}

The proposed design is generated using the creation of an arc in the conventional model and is presented in the next subsection. Later, the proposed design is optimized to further improve the results presented in the subsequent section.

\subsection{Hexagonal Conventional and Proposed Model Magnets}

The conventional and proposed hexagonal magnets' shapes are shown in Figure 3. The length and width, as shown in Figure 3, are kept the same in both the conventional and proposed models. Moreover, the volume of both of the models is also kept constant. However, the height of the PMs is different in order to keep the volume of the magnets constant. In order to preserve the constant volume, magnetic thickness is increased.

\subsection{Optimization of Proposed Model}

The asymmetric magnetic overhang concept is utilized to optimize the proposed model. The dimensions of the PM are varied by the inner and outer overhang. Extending the magnet on the upper side is termed as the upper overhang, and that on the lower side is the lower overhang. The volume of the magnet is kept constant. The magnets' inner width, outer width, and height are also varied, as shown in Figure 4. The limits of the variables are shown in Figure 4. 


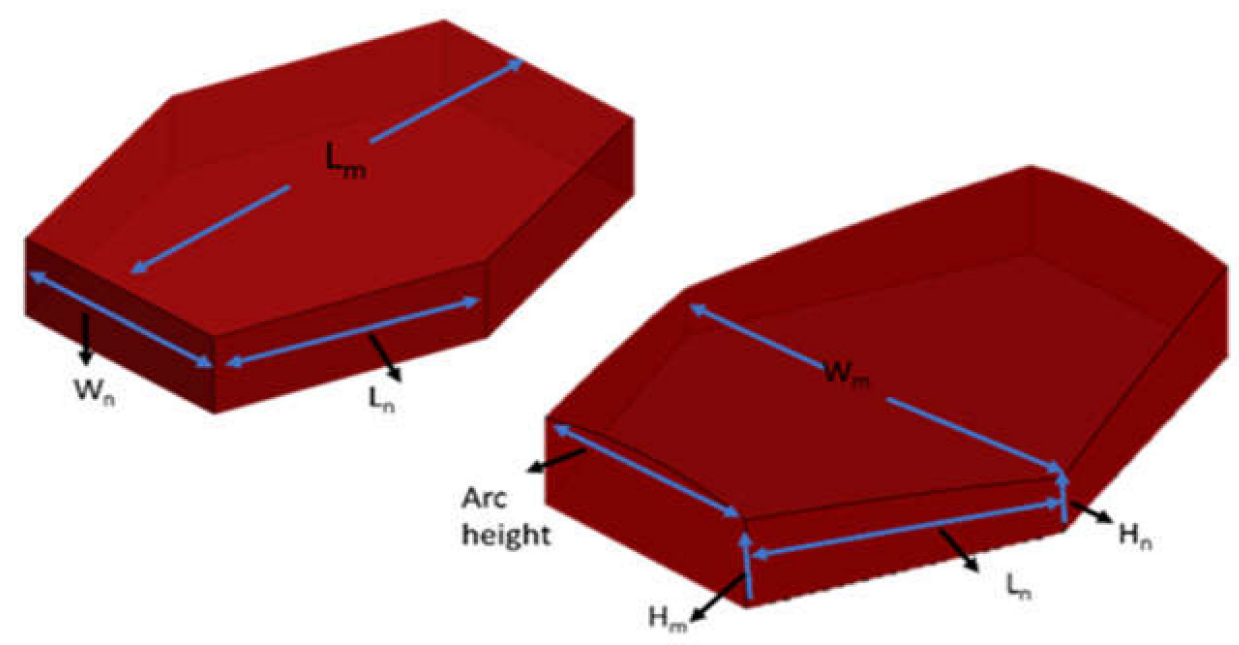

Figure 3. Conventional and proposed hexagonal-shaped magnets for AFPM machines.

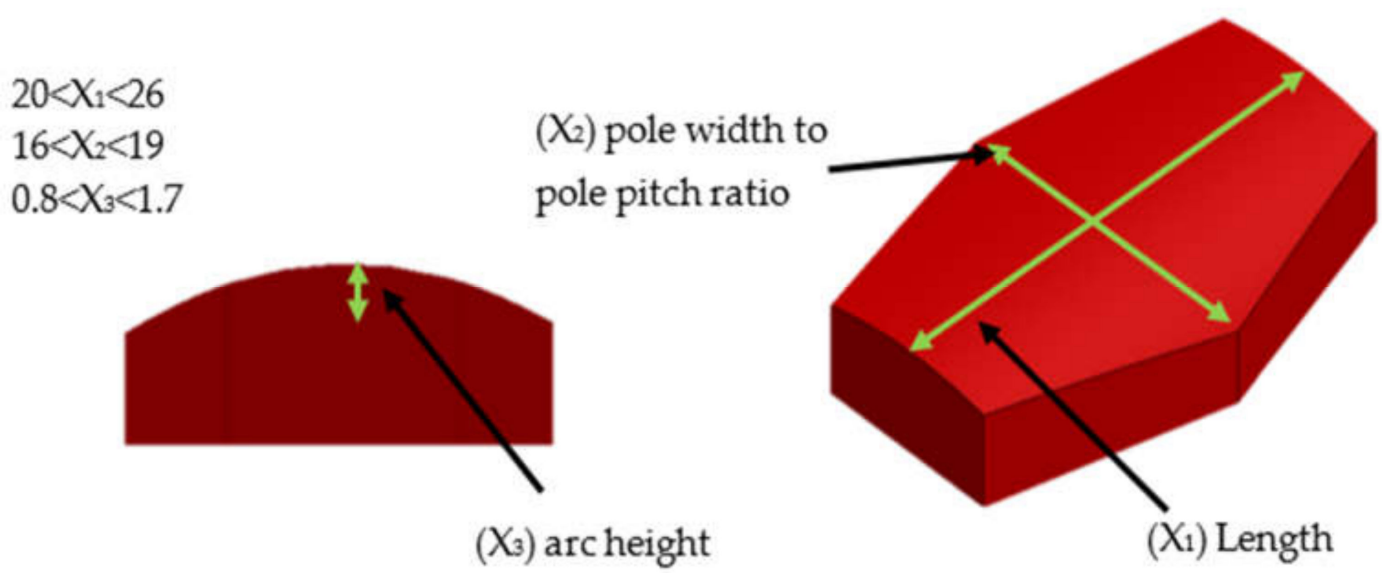

Figure 4. Variables (overhang, height, and width) for optimization of the axial flux permanent magnet machine.

\section{Results and Discussion of Conventional vs Proposed Model}

In this section, the various types of results are produced using the 3D transient FEA of both the conventional and proposed models. The proposed model is compared with the conventional model to show its improvements. The comparison is performed for cogging torque, back-EMF, three-phase voltage, $\mathrm{V}_{\mathrm{THD}}$, torque, torque ripples, and power.

\subsection{Comparison of Cogging Torque and Back-EMF of Conventional and Proposed Models}

The cogging torque and back-EMF of the conventional and proposed models are shown in the graphs in Figures 5 and 6. The peak-to-peak cogging torque of the conventional model is $0.705 \mathrm{Nm}$ and that of the proposed model is $0.45 \mathrm{Nm}$. The cogging torque is reduced in the proposed model due to the change in PM shape. There is a significant reduction in the cogging torque due to the proposed magnet shape. The percentage reduction in the cogging torque of the proposed model is $36.17 \%$. This reduction in the cogging torque is due to the large, effective air-gap in the proposed model, which decreases the air-gap flux in the machine. Back-EMF in the proposed model is lower than in the conventional model due to the enhancement of the effective air-gap length. The back-EMF of the proposed and conventional models is $109.361 \mathrm{~V}_{\mathrm{rms}}$ and $109.092 \mathrm{~V}_{\mathrm{rms}}$, respectively. The decrease in back-EMF is $0.245 \%$. As can be seen, the decrease in cogging torque is more significant as compared to the decrease in the back-EMF. This is mainly because cogging torque is proportional to the square of the air-gap flux. 


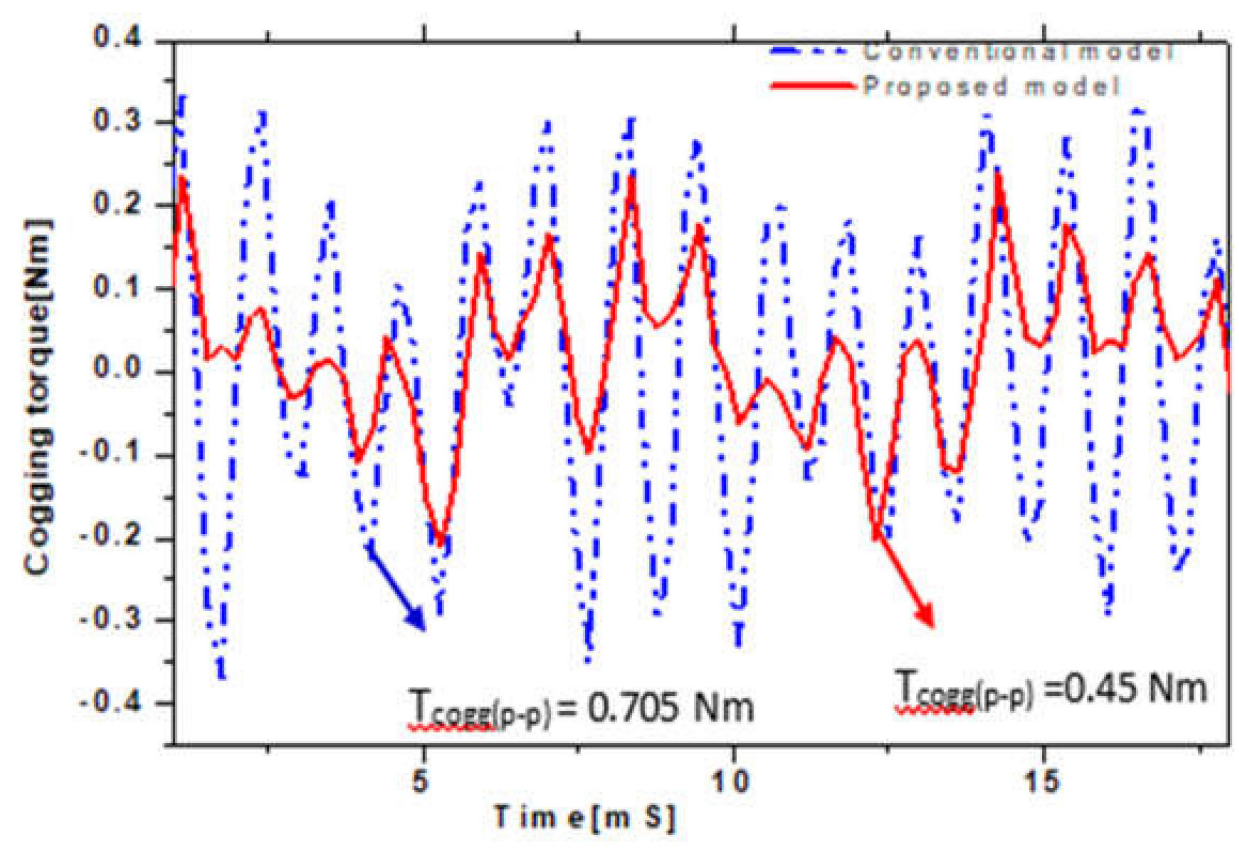

Figure 5. Cogging torque comparison for the conventional and proposed models.

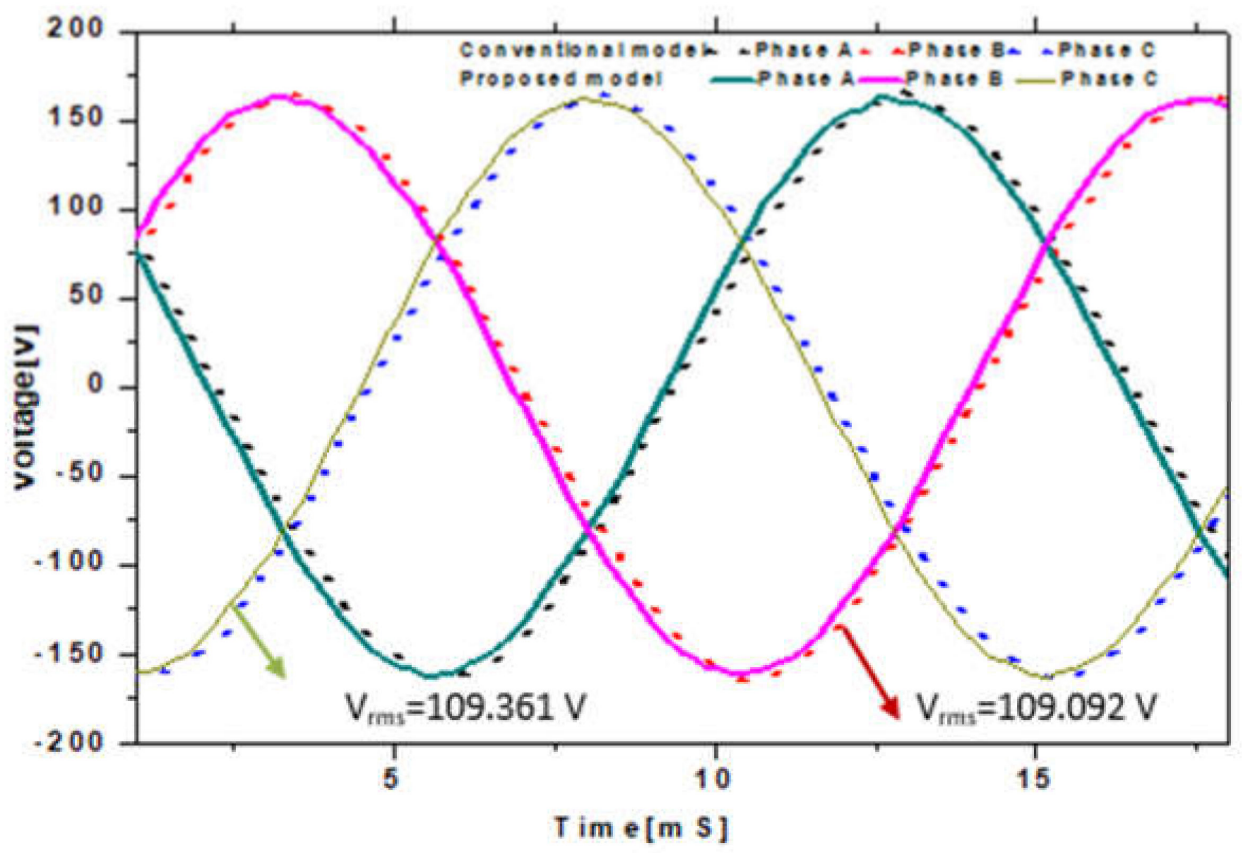

Figure 6. Voltage comparison of the conventional and proposed models.

\subsection{Voltage Total Harmonic Distortion $\left(V_{T H D}\right)$ of the Conventional and Proposed Models}

The $\mathrm{V}_{\mathrm{THD}}$ of both the conventional and proposed models is shown in Figure 7 . The $\mathrm{V}_{\mathrm{THD}}$ of the conventional hexagonal model is $1.33 \%$ and the $\mathrm{V}_{\mathrm{THD}}$ of the proposed hexagonal model is $0.789 \%$. The percentage decrease in $\mathrm{V}_{\mathrm{THD}}$ is $40.6 \%$. Thus, the proposed model has enhanced the fundamental back-EMF component as compared to the conventional model, due to the arc hexagonal-shaped PM. Thus, with the proposed PM shape's smoothness in the back-EMF is enhanced, which will be helpful in further reducing the torque ripples. 


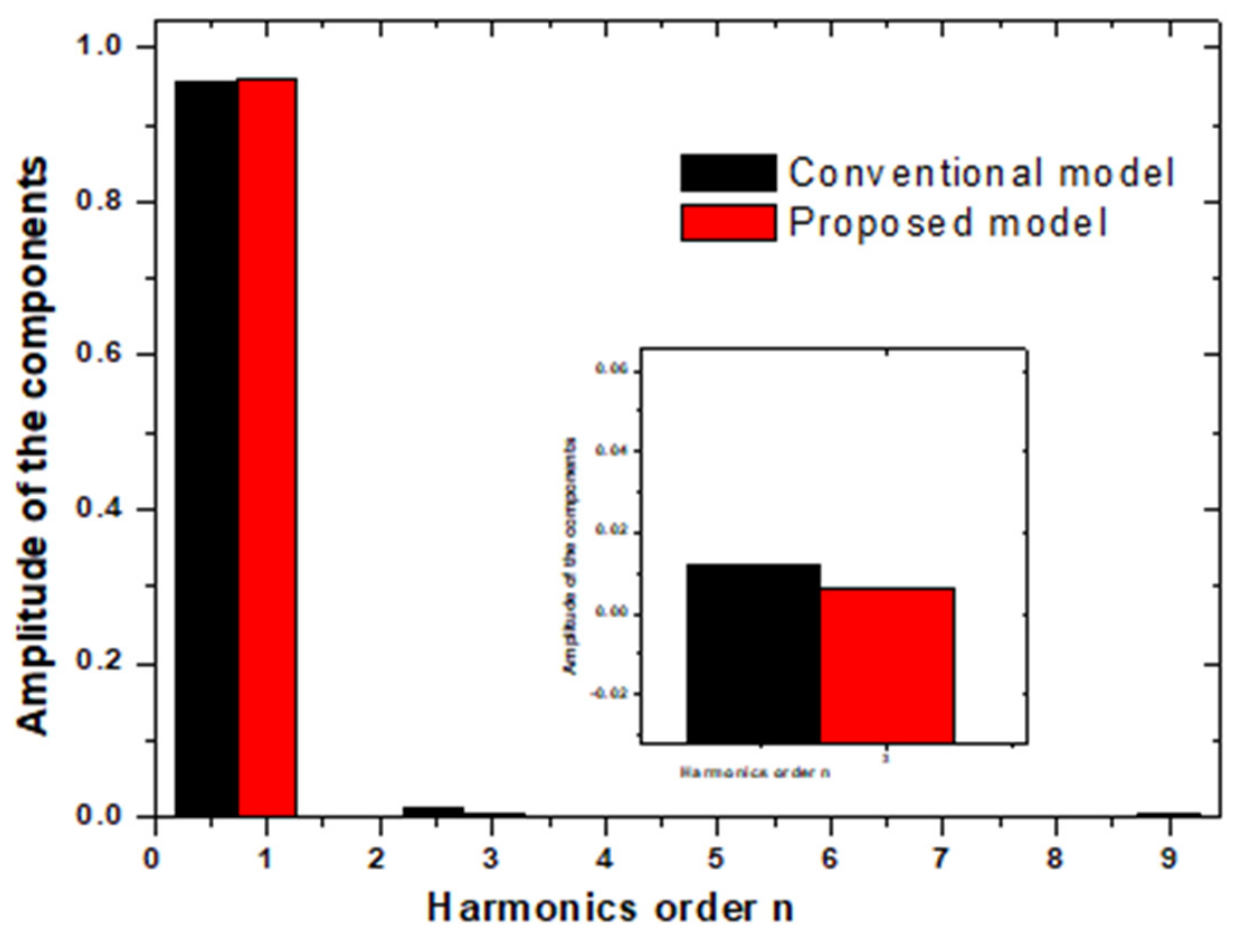

Figure 7. Voltage Total Harmonic Distortion of the conventional and proposed models.

\subsection{Torque Analysis of Conventional and Proposed Models}

The conventional and proposed models' output torque is shown in Figure 8. The output torque of the conventional and proposed models is $3.5984 \mathrm{Nm}$ and $3.56787 \mathrm{Nm}$, respectively. The output torque of both of the models is almost equal because both models have the same back-EMF. The torque ripples of the conventional model are $18.89 \%$ and those of the proposed model are $12.1 \%$. Hence, with the proposed model, the amount of torque ripple is reduced significantly by $35.94 \%$, and there is no significant change in average output torque.

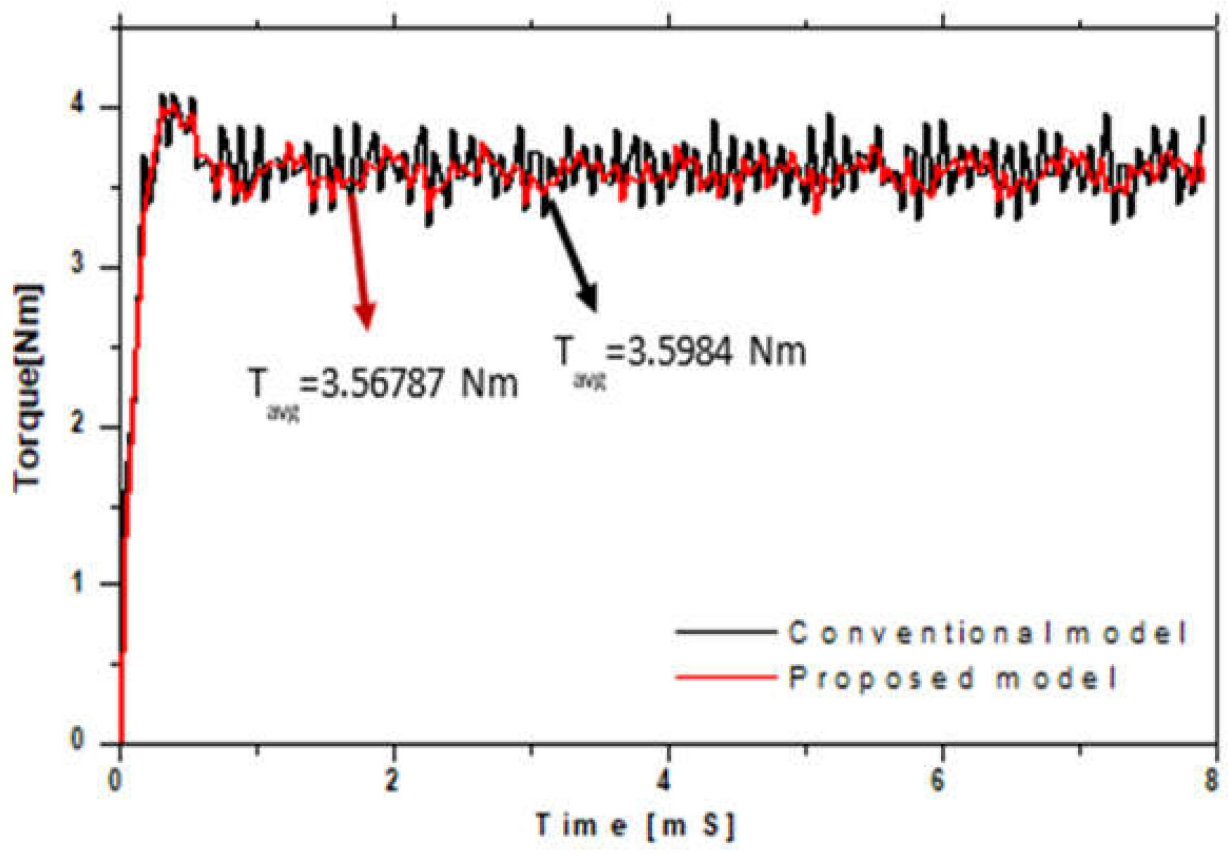

Figure 8. Comparison of output torque for the conventional and proposed models. 


\subsection{Comparison of Conventional and Proposed Models}

The performance comparison of the conventional flat hexagonal and the proposed arc hexagonal magnet models is specified in Table 2. Table 2 shows that the conventional model provides the most $\mathrm{V}_{\mathrm{rms}}, B_{g}$, torque ripples, $\mathrm{V}_{\mathrm{THD}}$, and $\mathrm{T}_{\text {cogging. }}$ Table 2 shows that cogging torque and torque ripples are reduced in the proposed model. Further, the air-gap flux density of the proposed model is reduced compared to the conventional model. Moreover, the results show that the reduction in $\mathrm{V}_{\mathrm{THD}}$ is achieved with the proposed model in comparison to the conventional model. Furthermore, the back-EMF and torque levels in both of the models are almost the same.

Table 2. Performance Comparison of Conventional and Proposed Model.

\begin{tabular}{cccc}
\hline Model & Conventional & Proposed & Units \\
\hline Voltage $\left(\mathrm{V}_{\text {rms }}\right)$ & 109.361 & 109.092 & $\mathrm{~V}$ \\
\hline Cogging torque & 0.705 & 0.45 & $\mathrm{Nm}$ \\
\hline$B_{g}(\mathrm{rms})$ & 0.548 & 0.496 & $\mathrm{~T}$ \\
\hline $\mathrm{V}_{\mathrm{THD}}$ & 1.33 & 0.789 & $\%$ \\
\hline Torque & 3.59 & 3.56 & $\mathrm{Nm}$ \\
\hline Torque ripples & 18.89 & 12.1 & $\%$ \\
\hline
\end{tabular}

\section{Optimized Model Results and Discussion}

The asymmetric magnetic overhang concept is utilized to optimize the proposed model, as shown in Figure 9. The dimensions of the PM are varied by the inner and the outer overhang. Extending the magnet on the upper side is termed as the upper overhang, and that on the lower side is the lower overhang. The volume of the magnet is kept constant. The inner width, outer width, and height of the magnets are also varied. Latin Hyper Cube (LHS) sampling is used to create the experiments. The krigging is used to approximate the function, and a genetic algorithm is used for the minimization of the objective function. The volume of the magnet is kept constant. The minimization of the cogging torque and the maximization of the back-EMF are the objective functions. The objective functions, constraints, and limits of the variables are described in (10), (11), and (12), respectively.

Maximize the voltage

Minimize the cogging torque

Cogging torque $<0.45 \mathrm{Nm}$

Voltage $>109.092$

$$
\begin{gathered}
20 \leq X_{1} \leq 26 \\
16 \leq X_{2} \leq 19 \\
0.8 \leq X_{3} \leq 1.7
\end{gathered}
$$

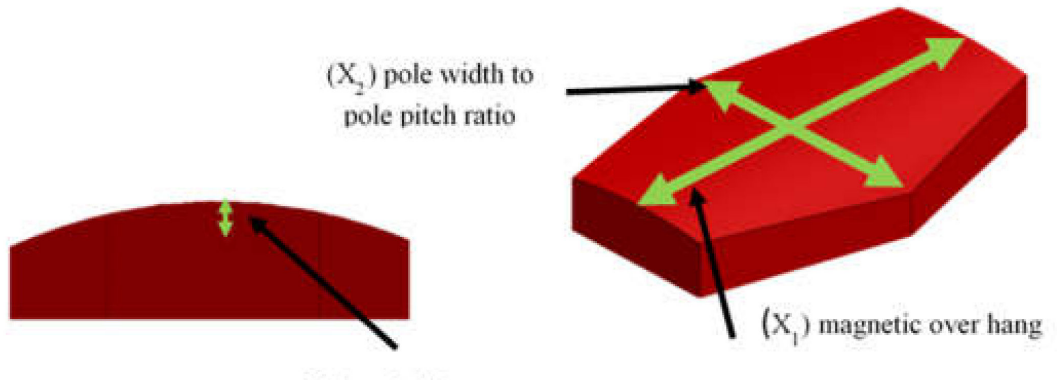

$\left(\mathrm{X}_{3}\right)$ arc height

Figure 9. Variables for optimization. 
The convergence process of optimization for the objective functions and design variables is shown in Figures 10 and 11, respectively. The cogging torque is reduced from 0.45 to 0.35 , and voltage is increased from $109 \mathrm{~V}$ to $112.59 \mathrm{~V}$. Then, the results are verified through finite element analysis.

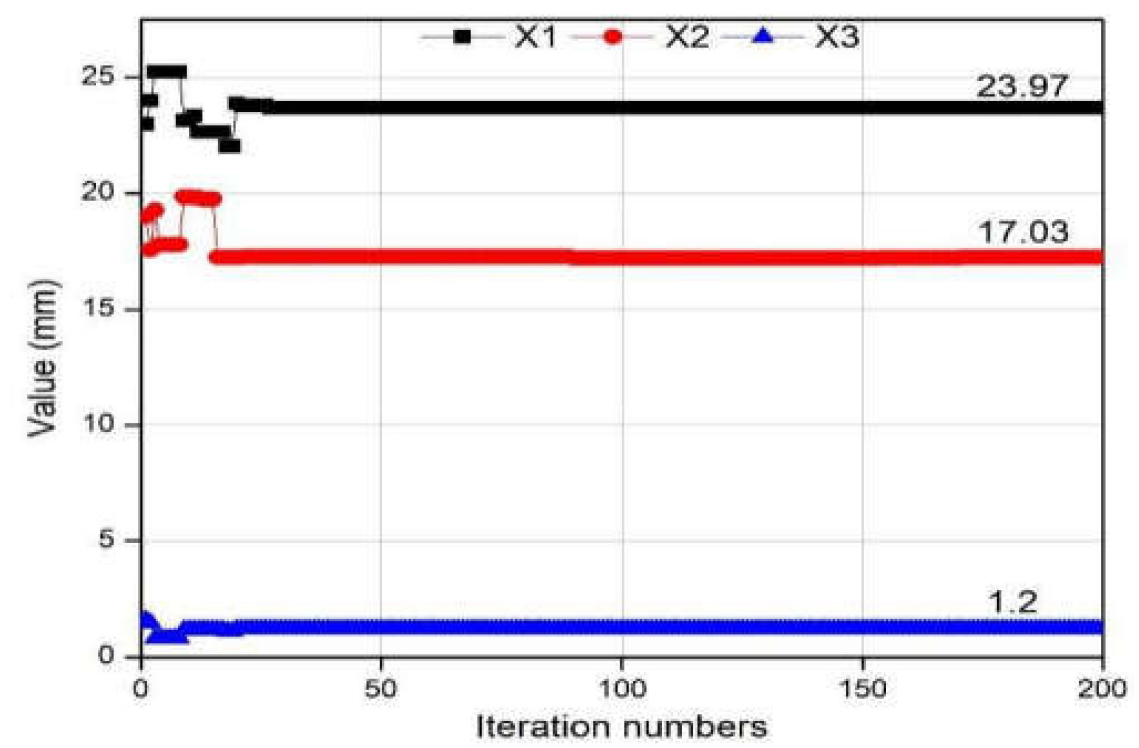

Figure 10. Convergence process for design variables.

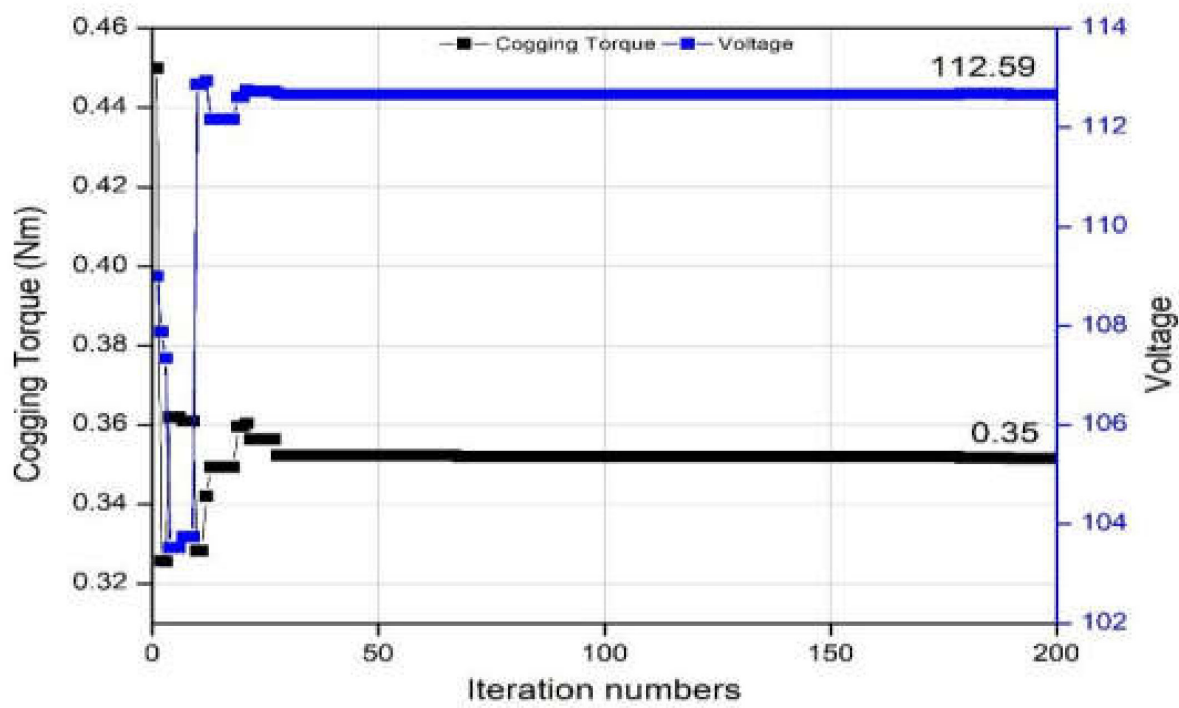

Figure 11. Convergence process for objective functions.

\subsection{Voltage and Cogging Torque Improvement in the Optimized Model}

Voltage is improved in the optimized model, from $109.361 \mathrm{~V}_{\text {rms }}$ to $112.592 \mathrm{~V}_{\mathrm{rms}}$. The voltage comparison graph of the proposed and optimized models is shown in Figure 12. A considerable reduction in cogging torque is achieved during the optimization process, and the cogging torque is reduced from $0.45 \mathrm{Nm}$ to $0.356 \mathrm{Nm}$. Figure 13 shows the improvements in cogging torque. The increase in back-EMF is obtained due to the asymmetric overhang effect, and the increase of $3.232 \mathrm{~V}$ is achieved while the reduction in cogging torque is $20.88 \%$. 


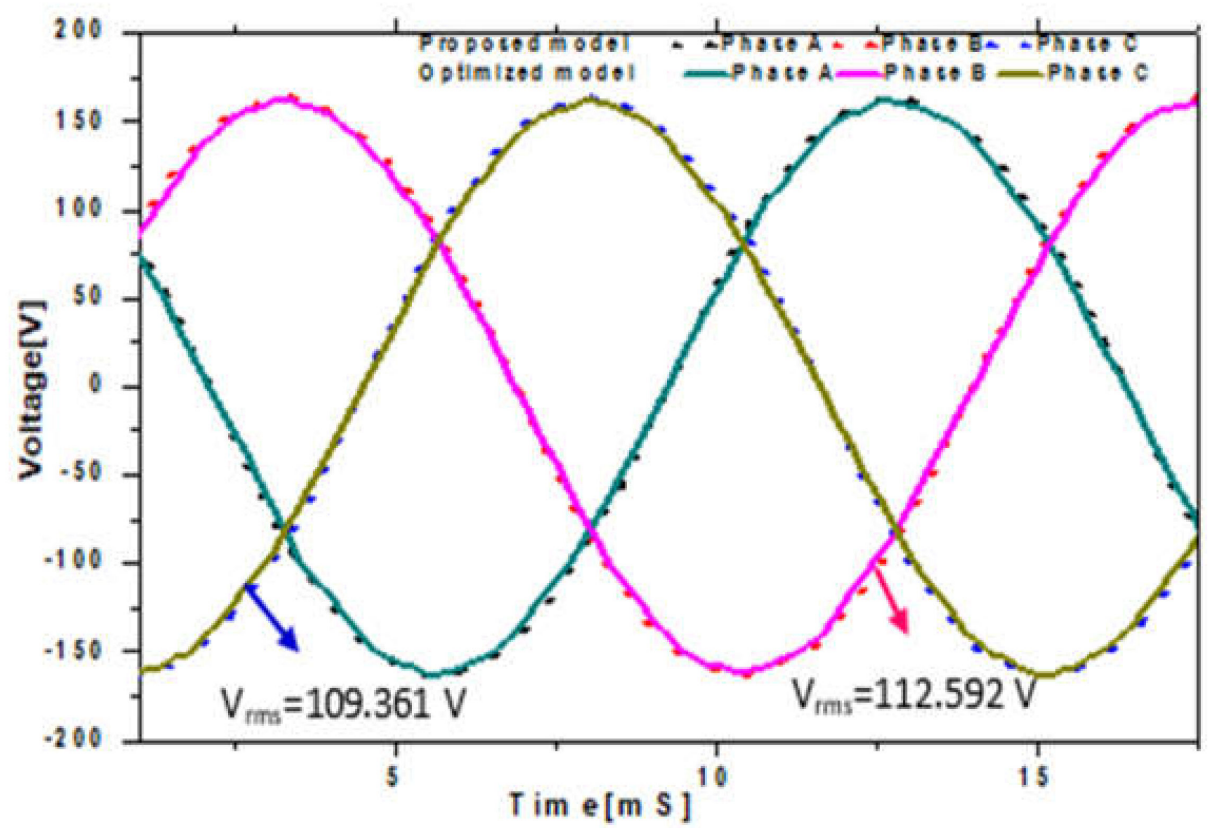

Figure 12. Voltage comparison of the proposed and optimized models.

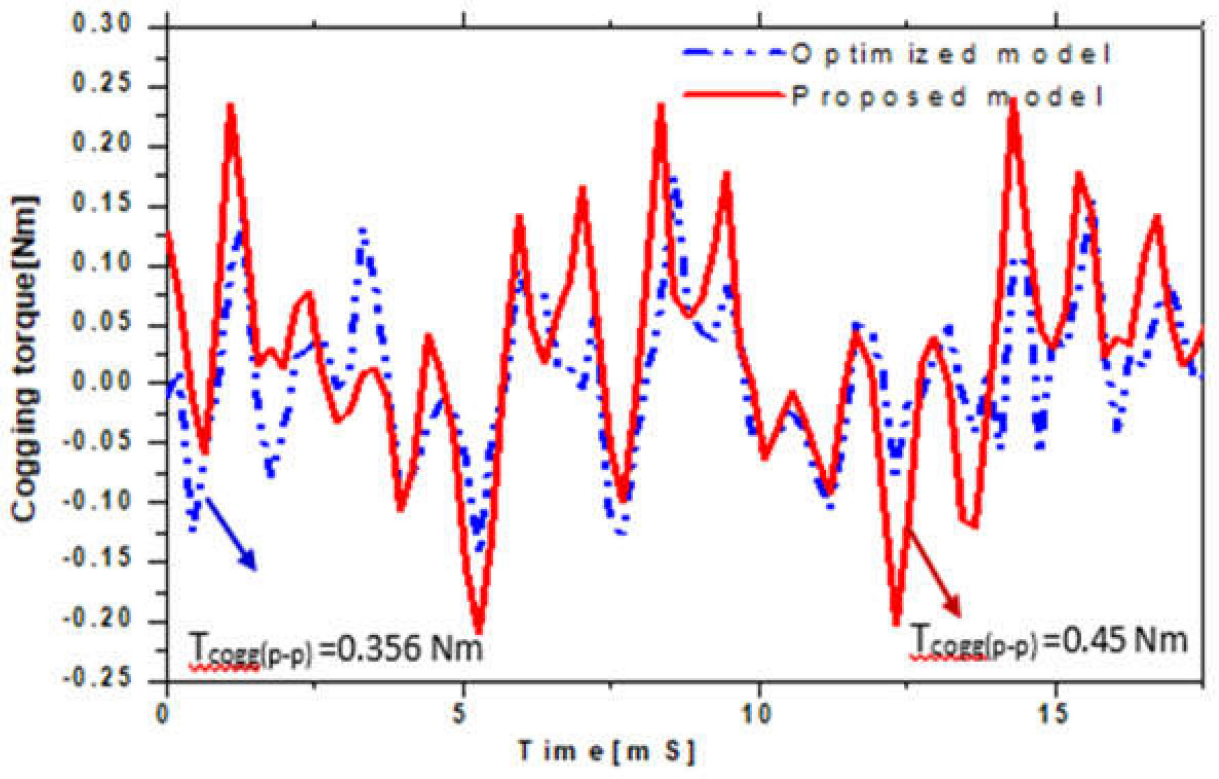

Figure 13. Cogging torque comparison of the proposed and optimized models.

\subsection{Power and Torque Analysis of Proposed and Optimized Models}

The output power of the machine is improved, through optimization, from $2.26 \mathrm{~kW}$ to $2.47 \mathrm{~kW}$. The output torque of the machine is improved from $3.859 \mathrm{Nm}$ to $3.643 \mathrm{Nm}$ peakto-peak in the proposed model. The enhancement achieved in the output power is $0.21 \mathrm{KW}$, and $0.2 \mathrm{Nm}$ torque enhancement is achieved in the optimized model. Moreover, a reduction in the torque ripple is achieved, from $12.1 \%$ to $9.55 \%$. during the optimization process. Figures 14 and 15 show the output power and torque of the proposed and optimized models. 


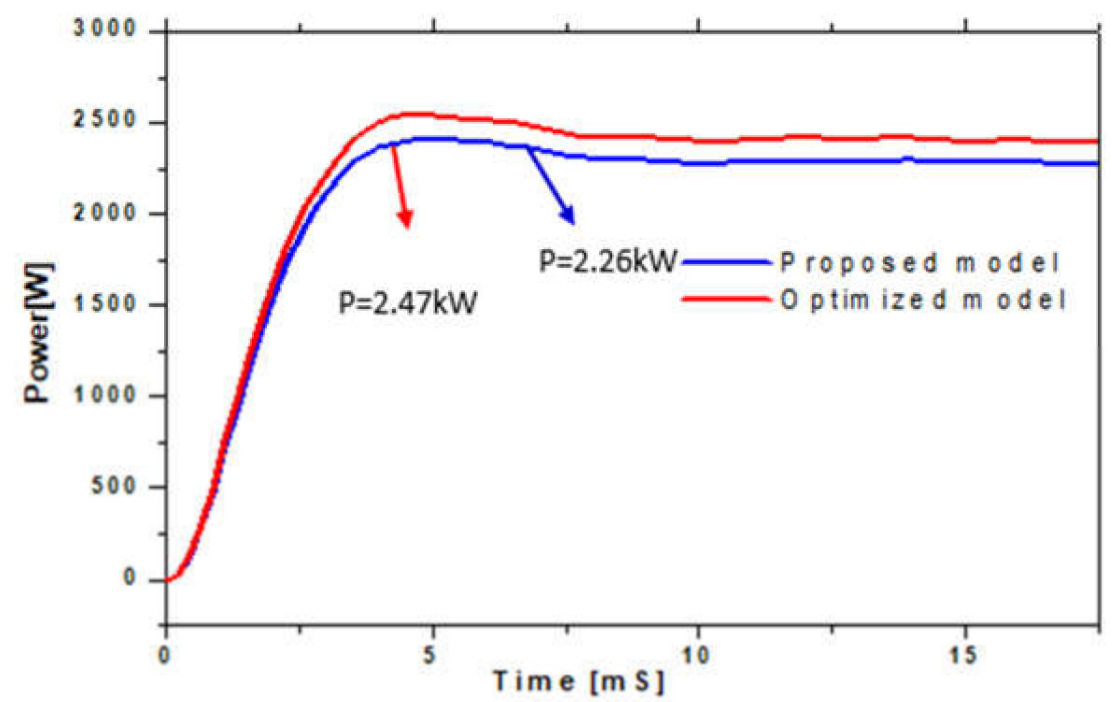

Figure 14. Comparison of power for the proposed and optimized models.

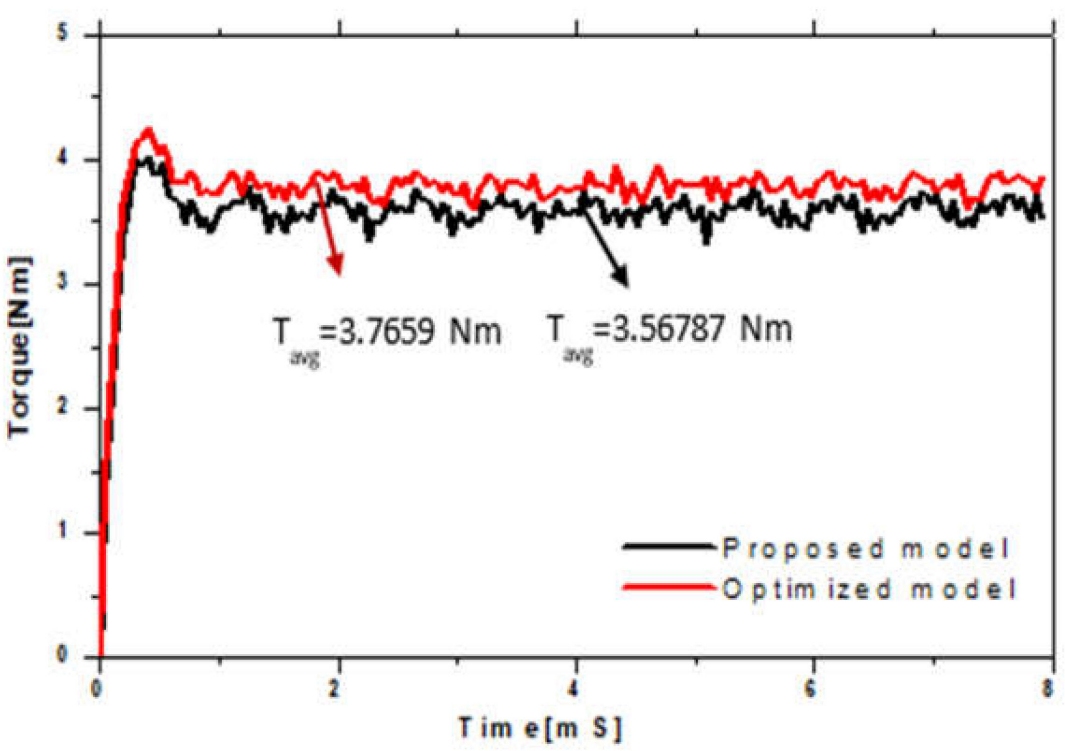

Figure 15. Torque comparison of the proposed and optimized models.

\subsection{Comparison of Performance for Proposed and Optimized Models}

The performance comparison of the proposed arc hexagonal magnets and the optimized model is provided in Table 3 , which includes $\mathrm{V}_{\mathrm{rms}}, B_{g}$, torque ripple, and $\mathrm{T}_{\text {cogging }}$. The table illustrates that minimum cogging torque, output torque ripples, and maximum voltage are achieved in the optimized model, and all of these performance parameters are summarized in Table 3.

Table 3. Performance Comparison of Conventional and Proposed Models.

\begin{tabular}{cccc}
\hline Model & Proposed & Optimized & Units \\
\hline Voltage $\left(\mathrm{V}_{\text {rms }}\right)$ & 109.092 & 112.592 & $\mathrm{~V}$ \\
\hline Cogging torque & 0.745 & 0.356 & $\mathrm{Nm}$ \\
\hline$B_{g}(\mathrm{rms})$ & 0.496 & 0.481 & $\mathrm{~T}$ \\
\hline $\mathrm{V}_{\mathrm{THD}}$ & 0.789 & 1.9 & $\%$ \\
\hline Torque ripples & 12.1 & 9.55 & $\%$ \\
\hline
\end{tabular}




\section{Conclusions}

An AFPM machine with an arc hexagonal magnet shape is proposed to decrease cogging torque. In the proposed model, cogging torque is reduced, and output torque has been reduced due to an increase in air-gap length as compared to the conventional model. The $\mathrm{V}_{\mathrm{THD}}$ of the conventional hexagonal-shaped model is $1.33 \%$, and the $\mathrm{V}_{\mathrm{THD}}$ of the proposed model is $0.789 \%$; hence, the $\mathrm{V}_{\mathrm{THD}}$ is reduced in the proposed model. The arc hexagonal-shaped proposed model is then further optimized to achieve reduced cogging torque and increased output torque. In the optimized model, cogging torque and torque ripples are reduced, the output torque is improved, and power is also increased as compared with the proposed hexagonal model. The performance characteristics of the optimized model exhibit improved results relative to the proposed and conventional models.

Author Contributions: Conceptualization, J.I.; software, H.U. and M.Y.; formal analysis, H.U., M.Y., and K.S.A.; writing — original draft preparation, S.S.H.B.; funding acquisition, J.-S.R. All authors have read and agreed to the published version of the manuscript.

Funding: National Research Foundation of Korea, 2016R1D1A1B01008058; the Brain Pool (BP) Program, 2019H1D3A1A01102988.

Acknowledgments: This work was supported in part by the Brain Pool (BP) Program, funded by the Ministry of Science and ICT through the National Research Foundation of Korea under Grant 2019H1D3A1A01102988, and in part by the Basic Science Research Program through the National Research Foundation of Korea, funded by the Ministry of Education under Grant 2016R1D1A1B01008058.

Conflicts of Interest: The authors declare no conflict of interest.

\section{References}

1. Honsinger, V.B. Performance of polyphase permanent magnet machines. IEEE Trans. Power Appar. Syst. 1980, 4, 1510-1518. [CrossRef]

2. Huang, S.; Luo, J.; Leonardi, F.; Lipo, T.A. A general approach to sizing and power density equations for comparison of electrical machines. IEEE Trans. Ind. Appl. 1998, 34, 92-97. [CrossRef]

3. Taran, N.; Heins, G.; Rallabandi, V.; Patterson, D.; Ionel, D.M. Torque Production Capability of Axial Flux Machines with Single and Double Rotor Configurations. In Proceedings of the 2018 IEEE Energy Conversion Congress and Exposition (ECCE), Portland, OR, USA, 23-27 September 2018.

4. Ahmadi Darmani, M.; Hooshyar, H. Optimal Design of Axial Flux Permanent Magnet Synchronous Motor for Electric Vehicle Applications Using GAand FEM. J. Electr. Comput. Eng. Innov. 2015, 3, 89-97.

5. Lee, C.; Liu, C.; Chau, K. A Magnetless Axial-Flux Machine for Range-Extended Electric Vehicles. Energies 2014, 7, 1483-1499. [CrossRef]

6. Luo, X.; Niu, S. Maximum Power Point Tracking Sensorless Control of an Axial-Flux Permanent Magnet Vernier Wind Power Generator. Energies 2016, 9, 581. [CrossRef]

7. Hedlund, M.; Kamf, T.; De Santiago, J.; Abrahamsson, J.; Bernhoff, H. Reluctance Machine for a Hollow Cylinder Flywheel. Energies 2017, 10, 316. [CrossRef]

8. Kappatou, J.; Zalokostas, G.; Spyratos, D. 3-D FEM Analysis, Prototyping and Tests of an Axial Flux Permanent-Magnet Wind Generator. Energies 2017, 10, 1269. [CrossRef]

9. Mohamed, A.; Hemeida, A.; Vansompel, H.; Sergeant, P. Parametric Studies for Combined Convective and Conductive Heat Transfer for YASA Axial Flux Permanent Magnet Synchronous Machines. Energies 2018, 11, 2983. [CrossRef]

10. Amin, S.; Khan, S.; Bukhari, S.S.H. A Comprehensive Review on Axial Flux Machines and Its Applications. In Proceedings of the 2019 2nd International Conference on Computing, Mathematics and Engineering Technologies (iCoMET), Sukkur, Pakistan, 30-31 January 2019.

11. Aydin, M.; Zhu, Z.Q.; Lipo, T.A.; Howe, D. Minimization of cogging torque in axial-flux permanent-magnet machines: Design concepts. IEEE Trans. Magn. 2007, 43, 3614-3622. [CrossRef]

12. Kumar, P.; Srivastava, R.K. Influence of Rotor Magnet Shapes on Performance of Axial Flux Permanent Magnet Machines. Prog. Electromagn. Res. 2018, 85, 155-165. [CrossRef]

13. Aydin, M. Magnet skew in cogging torque minimization of axial gap permanent magnet motors. In Proceedings of the 200818 th International Conference on Electrical Machines, Vilamoura, Portugal, 6-9 September 2008.

14. Henrotte, F.; Hameyer, K. Computation of electromagnetic force densities: Maxwell stress tensor vs. virtual work principle. J. Comput. Appl. Math. 2004, 168, 235-243. [CrossRef] 
15. Ishak, D.; Zhu, Z.Q.; Howe, D. High torque density permanent magnet brushless machines with similar slot and pole numbers. J. Magn. Magn. Mater. 2004, 272, E1767-E1769. [CrossRef]

16. Zieliński, P.; Schoepp, K. Wolnoobrotowe generatory synchroniczne wzbudzane magnesami trwałymi o uzwojeniach skupionych. In Prace Naukowe Instytutu Maszyn, Napedów i Pomiarów Elektrycznych Politechniki Wrocławskiej, Studia i Materiaty; Oficyna Wydawnicza Politechniki Wrocławskiej: Wrocław, Poland, 2006.

17. Glinka, T. Maszyny Elektryczne Wzbudzane Magnesami Trwałymi; Wydawnictwo Politechniki Śląskiej: Gliwice, Poland, 2002.

18. Jonczyk, J.; Kołodziej, J. Modelowanie Zagadnie'n Polowych z Wykorzystaniem MES. Master's Thesis, Politechnika Opolska, Opole, Poland, 2004.

19. Yang, Y.; Wang, X.; Zhang, R.; Zhu, C.; Ding, T. Research of cogging torque reduction by different slot width pairing permanent magnet motors. In Proceedings of the 8th International Electric Machines and Systems Conference, Nanjing, China, 27-29 September 2005; pp. 367-370.

20. Zhu, Z.Q.; Howe, D. Influence of design parameters on cogging torque in permanent magnet machines. IEEE Trans. Energy Convers. 2000, 15, 407-412. [CrossRef]

21. Cetin, E.; Daldaban, F. Analyzing the profile effects of the various magnet shapes in axial flux PM motors by means of 3D-FEA. Electronics 2018, 7, 13. [CrossRef]

22. Shokri, M.; Rostami, N.; Behjat, V.; Pyrhönen, J.; Rostami, M. Comparison of performance characteristics of axial-flux permanentmagnet synchronous machine with different magnet shapes. IEEE Trans. Magn. 2015, 51, 1-6. [CrossRef]

23. Zhao, W.; Lipo, T.A.; Kwon, B.I. Material-efficient permanent-magnet shape for torque pulsation minimization in SPM motors for automotive applications. IEEE Trans. Ind. Electron. 2014, 61, 5779-5787. [CrossRef]

24. Ikram, J.; Khan, N.; Khaliq, S.; Kwon, B.I. Reduction of Torque Ripple in an Axial Flux Generator Using Arc Shaped Trapezoidal Magnets in an Asymmetric Overhang Configuration. J. Magn. 2016, 21, 577-585. [CrossRef]

25. Jo, W.; Cho, Y.; Chun, Y.; Koo, D. Characteristic analysis on overhang effect in axial flux PM synchronous motors with slotted winding. In Proceedings of the 2006 CES/IEEE 5th International Power Electronics and Motion Control Conference, Shanghai, China, 14-16 August 2006.

26. Lebensztajn, L.; Marretto, C.A.; Perdiz, F.A.; Costa, M.C.; Nabeta, S.I.; Dietrich, Á.B.; Chabu, I.E.; Cavalcanti, T.T.; Cardoso, J.R. A multi-objective analysis of a special switched reluctance motor. COMPEL-Int. J. Comput. Math. Electr. Electron. Eng. 2005, 24, 931-941. [CrossRef]

27. Nagalingam, U.; Mahadevan, B.; Vijayarajan, K.; Loganathan, A.P. Design optimization for cogging torque mitigation in brushless DC motor using multi-objective particle swarm optimization algorithm. COMPEL Int. J. Comput. Math. Electr. Electron. Eng. 2015, 34, 1302-1318. [CrossRef]

28. Gong, J.; Berbecea, A.C.; Gillon, F.; Brochet, P. Multi-objective optimization of a linear induction motor using 3D FEM. COMPELInt. J. Comput. Math. Electr. Electron. Eng. 2012, 31, 958-971. [CrossRef]

29. Bilal, M.; Ikram, J.; Fida, A.; Bukhari, S.S.H.; Haider, N.; Ro, J.S. Performance Improvement of Dual Stator Axial Flux Spoke Type Permanent Magnet Vernier Machine. IEEE Access 2021, 9, 64179-64188. [CrossRef]

30. Baig, M.A.; Ikram, J.; Iftikhar, A.; Bukhari, S.S.H.; Khan, N.; Ro, J.S. Minimization of cogging torque in axial field flux switching machine using arc shaped triangular magnets. IEEE Access 2020, 8, 227193-227201. [CrossRef]

31. Yousuf, M.; Khan, F.; Ikram, J.; Badar, R.; Bukhari, S.S.H.; Ro, J.S. Reduction of Torque Ripples in Multi-Stack Slotless Axial Flux Machine by Using Right Angled Trapezoidal Permanent Magnet. IEEE Access 2021, 9, 22760-22773. [CrossRef] 